\title{
OORSIG
}

\section{DIE OPLEIDINGSFUNKSIE VAN DIE GEREGISTREERDE VERPLEEGKUNDIGE - DEEL II}

\author{
M C Bezuidenhout en A A Basson
}

\section{RESULTATE}

Biografiese gegewens van die saalsusters

Die saalsusters wat as respondente by die studie betrek is, het in ouderdom gewissel van 20 tot 51 jaar en ouer. Die grootste aantal $(n=88 ; 73 \%)$ respondente val in die ouderdomsgroepe van 35 jaar en jonger. Dit blyk dus dat die jong saalsuster steeds sterk in die saalsituasie verteenwoordig is.

\section{DIE OPLEIDINGSFUNKSIE VAN DIE SAALSUSTER}

1. Die saalsuster se bydrae as saalbestuurder

\section{Leierskap}

Vanuit die volgende eienskappe van leierskap moes die saalsusters die eienskap selekteer wat by haar as persoon die sterkste en die swakste verteenwoordig is:

* soek en benut ondergeskiktes se idees en spesiale kundigheid

* empatiseer met probleme van ondergeskiktes

- ondersteuning van ondergeskiktes

- deel inligting met ondergeskiktes

* openbaar geloof en vertroue in u ondergeskiktes

* beklemtoon beloning, begeleiding en betrokkenheid by ondergeskiktes

Die eienskap wat by die grootste aantal saalsusters $(n=31 ; 26 \%)$ as die sterkste eienskap na vore getree het was beloning, begeleiding en betrokkenheid by hul ondergeskiktes. Die eienskappe wat die saalsusters as die swakste verteenwoordig beskou het is ondersteuning aan ondergeskiktes ( $n=9 ; 8 \%)$ en empatie met die probleme van ondergeskiktes $(n=8 ; 7 \%)$.

\section{Probleemoplossing}

Tydens die hantering van probleme blyk dit dat die saalsuster al die ander saalsusters daarby betrek $(n=70 ; 58 \%)$, eerder as om die betrokke personeel by die probleemoplossingsessie te betrek $(n=47 ; 39 \%)$.
Vertrouensverhouding

Die saalsusters handhaf meestal 'n vertrouensverhouding met hul studentverpleegkundiges $(n=68 ; 57 \%)$. Dié mening word deur die studentverpleegkundiges bevestig aangesien $144(73 \%)$ angetoon het dat hulle ' $n$ vertrouensverhouding met hul saalsusters gehad het. 'n Kwart van die studentverpleegkundiges $(n=52 ; 27 \%)$ het egter nie hul verhouding met die saalsuster as 'n vertrouensverhouding beleef nie.

\section{Houding van die saalsuster}

Die houding van die saalsuster teenoor die studentverpleegkundiges is deur 157 (80\%) studente as vriendelik, toeganklik en bemoedigend beleef, terwyl $32(16 \%)$ haar as afsydig en neutraal ondervind het. Sewe (4\%) het die saalsuster ontoeganklik gevind.

\section{Weeklikse werkverdeling}

Wat die saalsuster se weeklikse werkverdeling van haar eie tyd betref, kom dit voor asof die grootste gedeelte van haar tyd aan administratiewe take afgestaan word. Die saalsusters het aangetoon dat $78(65 \%)$ van hulle meer as 25 persent van hul tyd aan administrasie afstaan. (Dit is opmerklik dat 45 Saalsusters teenoor 33 saalsusters-in-bevel meer as $\mathbf{2 5}$ persent van hul tyd aan administrasie afstaan). $\mathrm{Na}$ verdere ontleding blyk dit dat $30(25 \%)$ van die respondente 50 persent en meer van hul tyd aan administratiewe take wy, verwys na Figuur 1 .

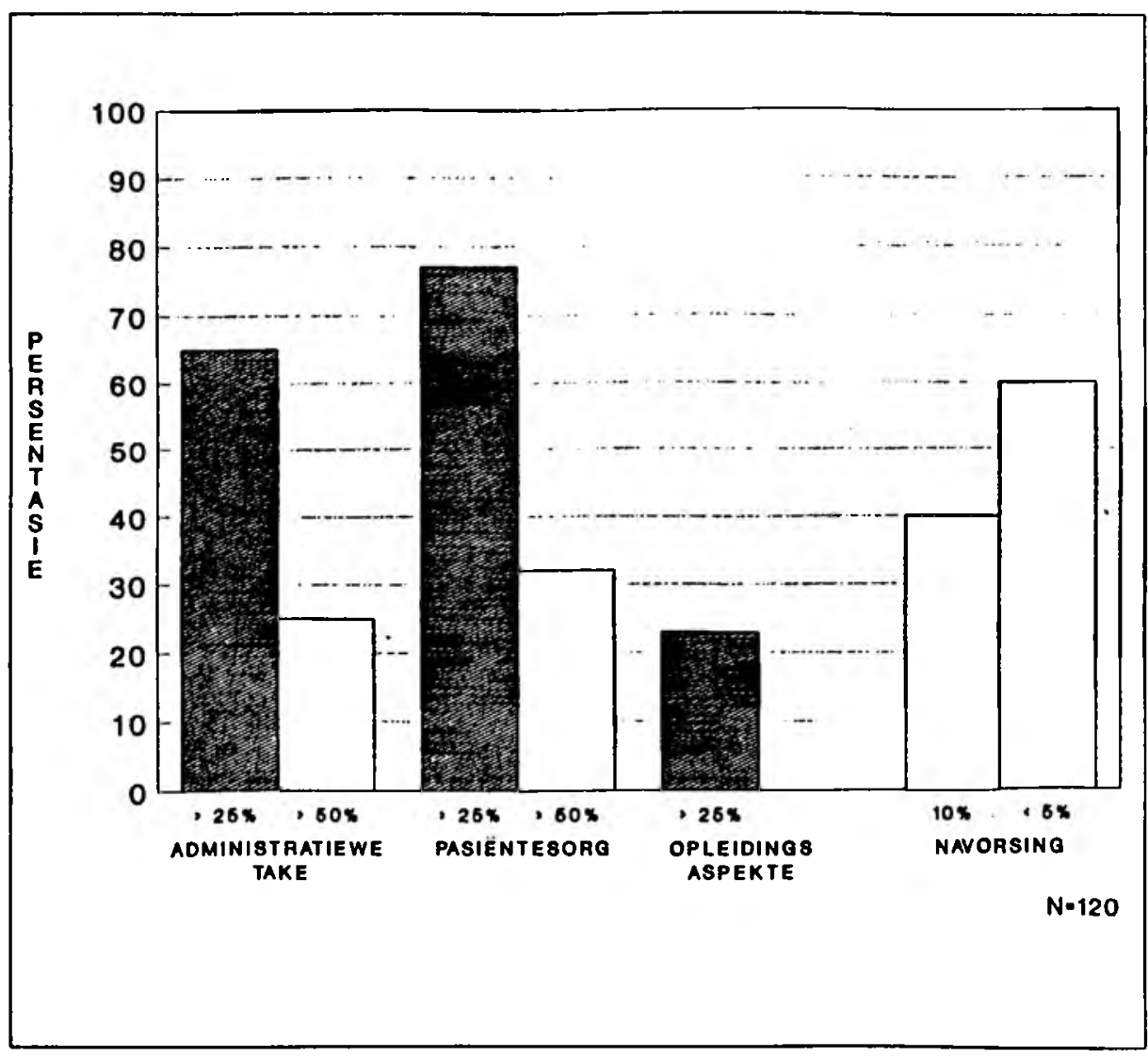

Figuur 1

Weekllkse werkverdeling van die saalsuster se ele tyd tussen haar administratiewe-, paslëntesorg-, opleidlings- en navorsingsfunksles 
Twee-en-negentig (77\%) saalsusters het aangetoon dat hulle meer as 25 persent van hul tyd aan pasiëntsorg afstaan. Agı-en-dertig (32\%) van die saalsusters het 50 persent en meer van hul tyd aan die pasiënte gewy.

Opleiding neem 'n swak derde plek wanneer dit kom by die tydsbenutting van die saalsuster aangesien slegs 28 (23\%) salsusters aangetoon het dat hulle 25 persent of meer van hul tyd aan opleidingsaspekte bestee.

Volgens $48(40 \%)$ respondente het navorsing 10 persent van hul tyd in beslag geneem.

\section{Werkslading}

Dic grootste getal saalsusters ( $n=81 ; 68 \%)$ het nie gevoel dat daar te veel binne werksverband van haar verwag word nie. Vyf-en-dertig (29\%) was egter van mening dat die werkslading onbillik is.

\section{Oriëntering}

Alhoewel doeltreffende orièntering van nuwe personeel deur die oorgrote meerderheid saalsusters $(n=118 ; 98 \%)$ as belangrik beskou is, is slegs ' $\mathrm{n}$ klein persentasie $(\mathrm{N}=18 ; 15 \%)$ saalsusters persoonlik by die oriëntering van hul personeel betrokke.

Een-en-tagtig (41\%) van die studentverpleegkundiges het gevoel dat hulle nie bevredigend en voldoende georiènteer was toe hulle vir die eerste keer in die betrokke sale vir diens aangemeld het nie.

Die studentverpleegkundiges dui verder aan dat die saalsuster in $90(46 \%)$ gevalle nie persoonlik by hul orièntering betrokke was nie.

Vereistes gestel aan die studentverpleegkundige

In die meeste $(n=167 ; 85 \%)$ gevalle het die studentverpleegkundiges aangedui dat die saalsuster se verwagtinge van haar as student duidelik bekend gemak is, sodat hulle as ondergeskiktes altyd geweet het wat die saalsuster van hulle verwag en waarvoor hulle verantwoordclik was. Figuur 2 dui die mening van die saalsusters aan in die verband.

Ses-en-sewentig (63\%) van die saalsusters was van mening dat die vereistes gestel aan die studentverpleegkundige met betrekking tot pasiëntsorg billik was. Die oorblywende $\mathbf{4 2}$ (3.5\%) saalsusters het hul kommer uitgespreek in dié verband om die volgende redes: die praktyk vereis dat sy gouer bevoeg moet wees in meer gevorderde prosedures as wat haar jaarvlak van opleiding aandui; die werklading is te groot en gevolglik word die studentverpleegkundige oorlaai met take waarvoor sy nog nie opgewasse is nie; hierbenewens is sy jonk en onervare en word te veel van haar verwag.

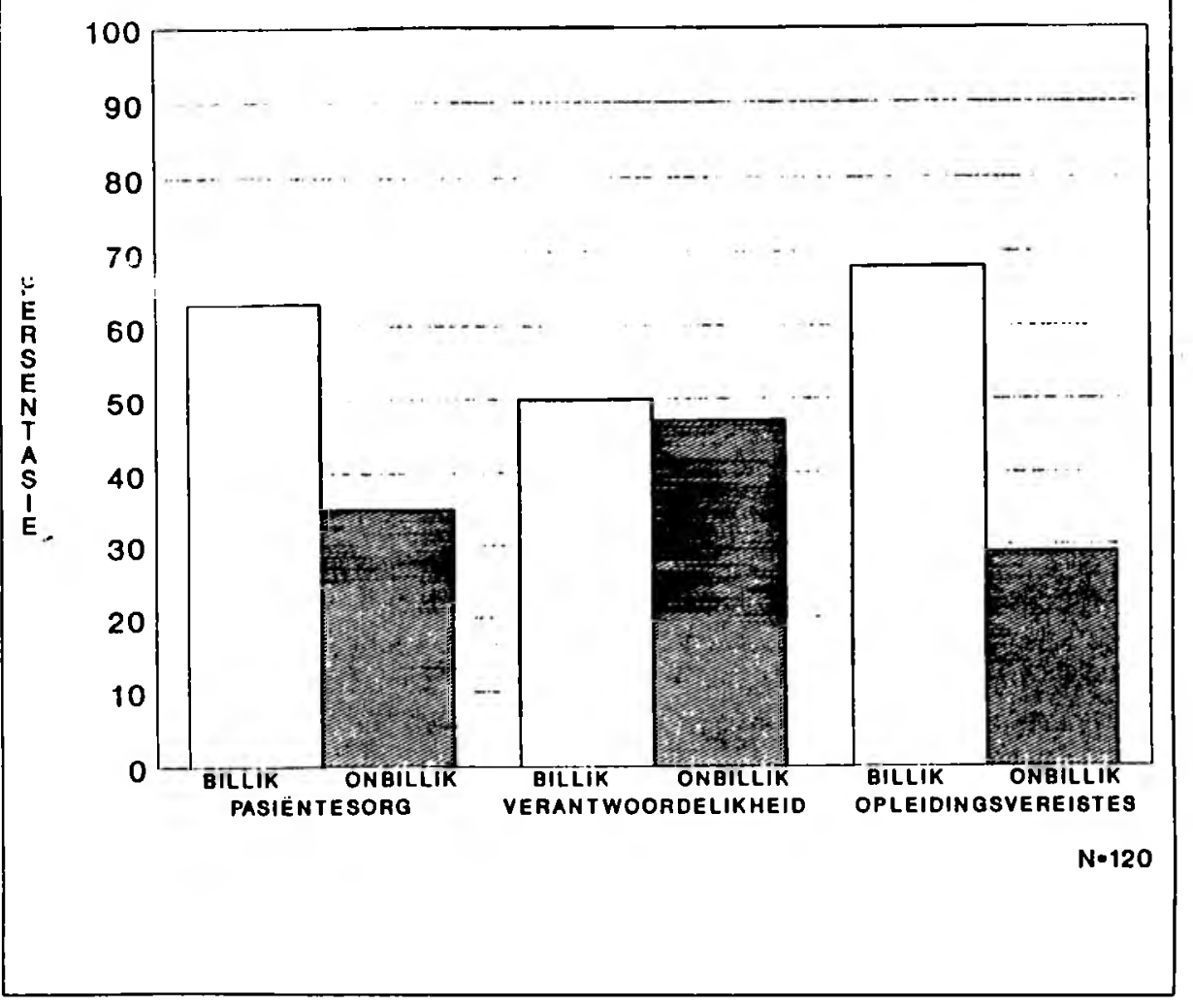

Figuur 2

Vereistes gestel aan die studentverpleegkundige M.B.T. pasientesorg, verantwoordelikheid en opleidingsvereistes s00s gesien deur die saalsuster
Die saalsusters was byna eweredig verdeel met betrekking tot hulle siening van die billikheid daarvan om van die studentverpleegkundiges te verwag om verantwoordelikheid ten opsigte van 'n wye verskeidenheid pligte te aanvaar. Sestig $(50 \%)$ glo dat die venwagtinge van die student in dié verband billik is, terwyl $56(47 \%)$ van mening is dat die verwagtinge om die volgende redes onbillik is: verantwoordelikheid word te vroeg op die skouers van die jong student geplaas, dit geld veral tydens die eerste en tweede jare van opleiding. ' $n$ Spesifieke terrein van bekommernis is dié van nagdiens, hierdie saalsusters voel dat te veel verantwoordelikheid op die onervare studentverpleegkundige geplaas word, sonder dat sy die nodige begeleiding en ondersteuning ontvang.

Die opleidingsvereistes van die studentverpleegkundige word deur 82 (68\%) van die saalsusters as geregverdig beskou. Vyf-en-dertig (29\%) is egter van mening dat daar te veel van die studente verwag word, veral in die tyd wat tot haar beskikking is. Die saalsusters huldig in die algemeen die mening dat die nuwe vierledige kursus 'n wanbalans tussen die teorie en die praktyk veroorsaak.

\section{Studentestatus}

Alhoewel daar met die vierledige kursus gepoog word om groter studentestatus aan die studentverpleegkundige te verleen, word sy nog deur $77(64 \%)$ van die saalsusters hoofsaaklik as werkkrag gesien, veral vanweě die feit dat daar nie ander personeel is om die versorging van die pasiënte waar te neem nie.

\section{Verpleegspan}

Die meeste studentverpleegkundiges $(n=173$; $88 \%$ ) was van mening dat hulle deel van die verpleegspan gevorm het en as sodanig behandel is. Drie-en-dertig (12\%) van die studente het egter gevoel dat hulle net daar was om die werk te verrig. Hulle is aangesê om take te verrig sonder ' $n$ verduideliking van waarom of hoe dit uitgevoer moes word. Hierdie respondente het aangedui dat hulle altyd die minderwaardige take moes doen.

\section{Inisiatief}

Inisiatief by ondergeskiktes is in $161(82 \%)$ gevalle deur die saalsusters aangemoedig, die oorblywende $(n=35 ; 18 \%)$ studentverpleegkundiges het hul saalsusters egter as ongenaakbaar en outokraties in die corweging van nuwe of alternatiewe idees beleef.

\section{Die saalsuster se betrokkenheid by kliniese onderrig}

Opleiding as deel van die saalsuster se taak Opleiding as deel van die saalsuster se taak is indirek deur al die saalsusters $(n=120 ; 100 \%)$ aanvaar deurdat hulle aangedui het dat hulle opleiding as essensieel beskou ten einde goeie pasiëntesorg te verseker. Die meerderheid saalsusters $(n=118 ; 98 \%)$ beskou opleiding as 'n noodsaaklike deel van die geregistreerde verpleegkundige se taak. Agt-en-tagtig (73\%) van die geregistreerde verpleegkundiges het 
aangedui dat hulle die saalsuster as die belangrikste onderwyser in die saalsituasie beskou, terwyl 43 (36\%) egter die kliniese dosent as die aangewese onderwyser gesien het.

Dat daar wel tyd vir opleiding in die saalsituasie is, is deur 101 (84\%) saalsusters bevestig.

Drie-en-tagtig (69\%) van die saalsusters meld dat hulle 'n doelbewuste poging aanwend om effektiewe onderrig 'n realiteit te maak.

Die studentverpleegkundiges dui aan dat daar nie 'n spesifieke saalsuster was wat verantwoordelikheid aanvaar het om toe te sien dat aandag aan opleidingsaangeleenthede geskenk word nie $(n=170 ; 87 \%)$. Dit het meegebring dat ' $n$ kundige persoon as konsultant nie altyd vir die studentverpleegkundiges beskikbaar was nie. Respondente is dikwels deur saalsusters wat nie tyd tot hul beskikking gehad het nie, weggewys. Dit blyk verder volgens die studentverpleegkundiges dat daar min of geen tyd vir opleiding was nie, min hulp en belangstelling is van sommige saalsusters verkry en geen opleiding het plaasgevind wanneer die kliniese dosent nie in die saal was nie.

\section{Benutting van leergeleenthede}

Om toepaslike leergeleenthede te kan benut is dit noodsaaklik dat insig verkry word in die studentverpleegkundige se bestaande kennis en ervaringsvlak alvorens nuwe inhoud daarby gevoeg word. Die meeste saalsusters ( $n=113$; $94 \%$ ) het aangedui dat hulle dit as hul verantwoordelikheid beskou om die vlak van ondervinding, kennis en vaardighede van hul ondergeskiktes te bepaal wanneer laasgenoemde vir die eerste keer in hul sale kom werk. Hierdie saalsusters het die studentverpleegkundiges uitgevra in $63(56 \%)$ gevalle, saam met haar gewerk in 94 (83\%) gevalle en haar opleidingsdokumente nageslaan in $19(17 \%)$ gevalle in 'n poging om haar vlak van opleiding te bepaal.

Dit blyk volgens die studentverpleegkundiges dat nie alle leergeleenthede deur die saalsusters benut word nie. Aldus 97 (49\%) studentverpleegkundige respondente het die saalsuster altyd of dikwels geleenthede benut om hulle te leer, te wys en te verduidelik.

Nege-en-negentig (51\%) studentverpleegkundiges het egter aangedui dat die salsuster slegs soms of nooit die geleenthede benut het nie.

Hierteencor was die meeste saalsusters ( $n=108$; 90\%) egter van mening dat hulle wel altyd of dikwels leergeleenthede tot voordeel van die studentverpleegkundiges benut het.

\section{Beplande onderrig}

Dit kom voor asof kliniese onderrig in die meeste sale op 'n lukraak grondslag plaasvind aangesien hierdie studentverpleegkundiges $(n=145 ; 74 \%)$ beweer dat daar geen

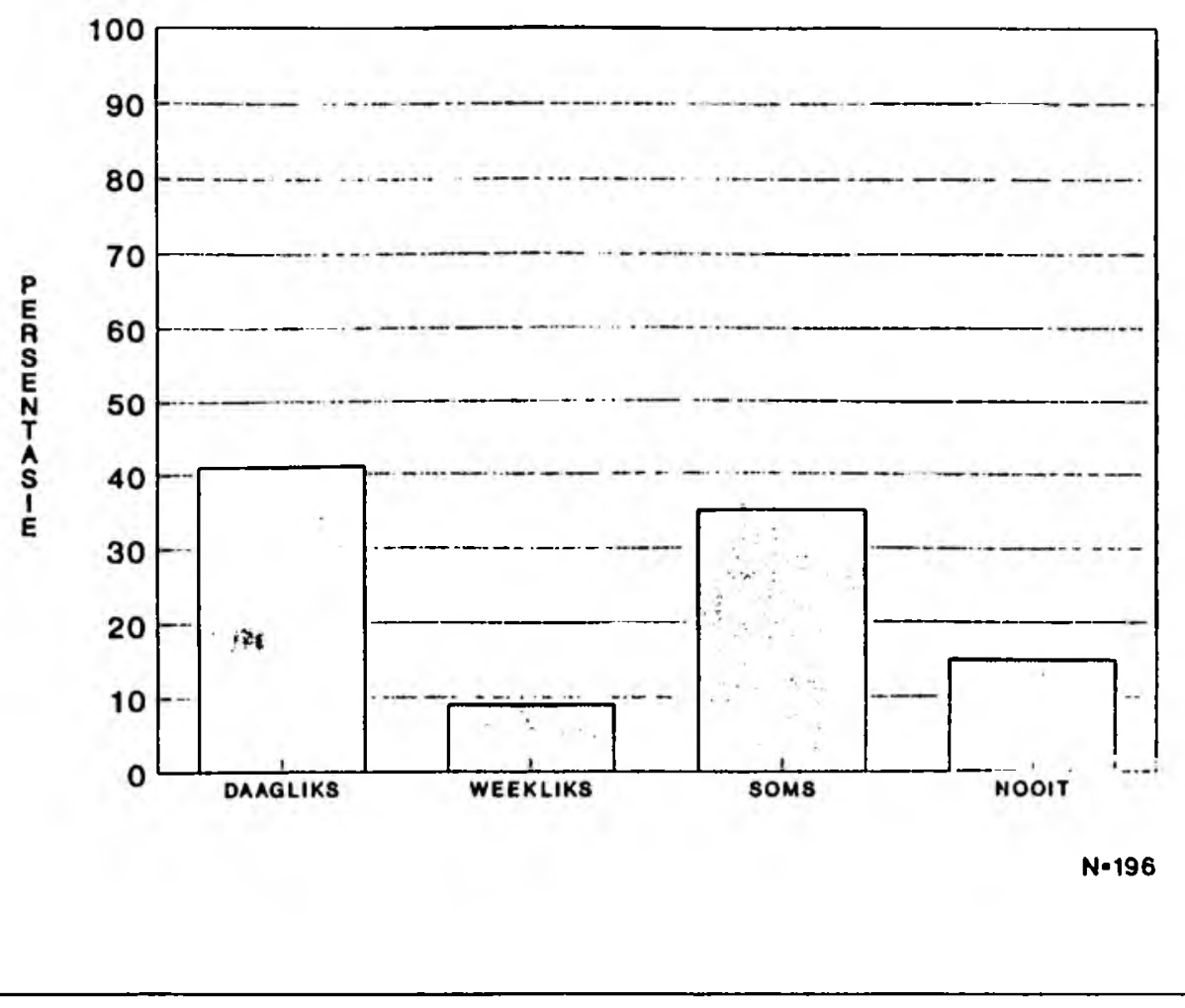

Figuur 3

Geleentheid vir die bespreking van saal- en pasientaangeleenthede as onderrig- en suiweringsforum volgens dle mening van studentverpleegkundiges

onderrigprogram deur die saalsusters vir haar bepaalde saal beplan of geimplementeer is nie.

\section{Geleentheid vir bespreking}

Geleentheid vir die bespreking van saal- en pasientaangeleenthede as onderrig-en suiweringsforum is nie op 'n gereelde grondslag deur meeste saalsusters voorsien nie. Figuur 3 dui die studentverpleegkundiges se siening met betrekking tot die frekwensie van die geleenthede aan. Die saalsusters daarteenoor toon dat $91(76 \%)$ van hulle wel sulke besprekingsgeleenthede voorsien.

Dat dit uitvoerbaar is word bevestig deur die saalsusters wat inderdaad die geleentheid daarvoor skep, byvoorbeeld tydens daaglikse saalrondtes met die personeel, of tydens gereelde indiensopleidingsessies waar alle kategorieè personeel ' $n$ inset kan lewer, asook op gereelde grondslag tydens die 10:00 verslag-oorgee periode.

\section{Persoonlike betrokkenheid van die} saalsuster

Ongeveer die helfte van die saalsusters ( $n=59$; $49 \%$ ) het aangetoon dat hulle dikwels hul studentverpleegkundiges op hoogte hou van hul kliniese vordering. Die studentverpleegkundiges beweer dat hulle in sommige $(n=47 ; 39 \%)$ gevalle of selfs nooit $(n=12 ; 10 \%)$ 'n vorderingsverslag van hul betrokke saalsuster met betrekking tot hul vordering in die saal, ontvang het nie.
Die studentverpleegkundiges het aangetoon dat die salsuster se persoonlike betrokkenheid by hul onderrig teleurstellend was. Die meeste studentverpleegkundiges $(n=99 ; 51 \%)$ beweer dat hul saalsusters wel soms persoonlik betrokke was, terwyl 'n verdere $28(14 \%)$ nooit die saalsuster se teenwoordigheid in enige onderrigmoontlikheid kon benut nie.

Indien die persoonlike betrokkenheid van die saalsuster by die kliniese onderrigsituasie gemeet word in terme van die aantal lesings, demonstrasies en verduidelikings wat sy per week gee, is haar betrokkenheid volgens die studentverpleegkundiges ondergemiddeld, aangesien 80 (41\%) soms, en 'n verdere 63 (32\%) nooit enige onderrig in bogenoemde formaat van die saslsusters ontvang het nie. 'n Groep van $53(27 \%)$ studentverpleegkundiges het wel dikwels die nodige lesings, demonstrasies en verduidelikings van hul saalsusters ontvang, verwys na Figuur 4.

Die response van die saalsusters bevestig bogenoemde waarneming van die studentverpleegkundiges aangesien die saalsusters aangedui het dat $66(55 \%)$ van die respondente vier of minder leergeleenthede per week aanbied. Een-en-veertig (34\%) van die saalsusters bied egter wel vyf tot tien leergeleenthede per week aan.

Die persoonlike betrokkenheid van die salsuster by onderrigaspekte kan in 'n mate 


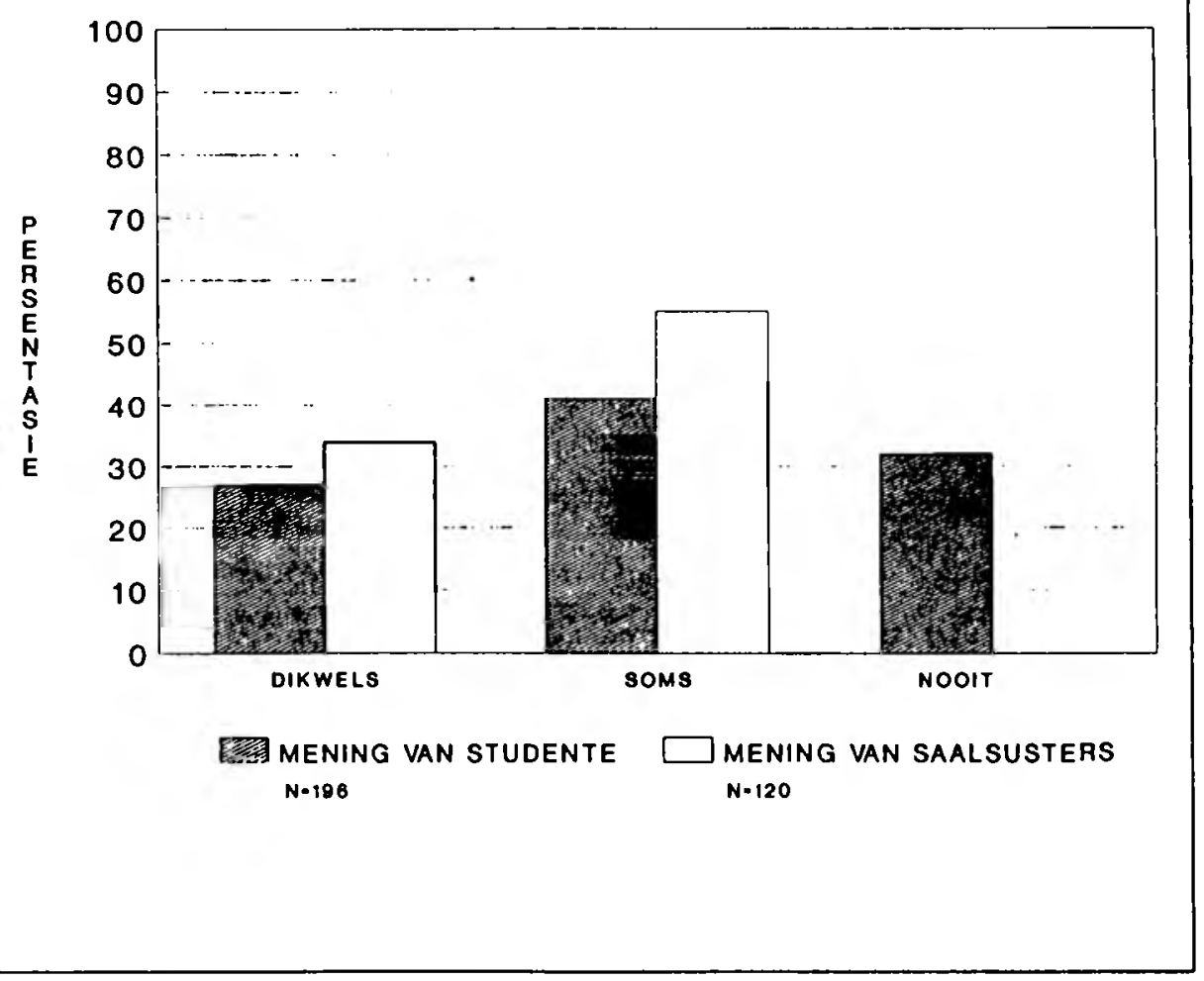

\section{Figuur 4 \\ Persoonllke betrokkenheid van die saalsuster by die klinlese onderrigsituasle gemeet in terme van die aantal lesings, demonstrasies en verduldellkIngs per week gegee}

verbind word aan die werklading en -tempo. Die navorser het geensins die werklading probeer bepaal nie, maar terugvoering deur die twee kategoriee respondente het egter voortdurend hiervan melding gemaak. So het $53(27 \%)$ van die studentverpleegkundiges aangedui dat die saalsuster geweier het om hulle te evalueer op grond daarvan dat daar nie genoegsame tyd beskikbaar was nie. In enkele gevalle was dit ook toeskryfbaar aan die gebrckkige kennis van die saalsuster.

\section{Bydrae van die saalsuster}

Een-honderd-sewe-en-twintig $(65 \%)$ van die studentverpleegkundiges het die saalsuster uit ses moontlike kategoriee verpleegpersoneel geselekteer as die persoon by wie sy die meeste in die betrokke saal geleer het.

\section{Opleidingsbehoeftes}

Studentverpleegkundiges beleef die feit dat hul dienste as werkkrag veel belangriker as hul opleiding skyn te wees, as 'n teleurstelling. Hulle besef dat hul opleiding 'n hoeveelheid praktika insluit, maar voel dat die kliniese praktika om opleiding moet gaan en nie primèr om hul dienste as werkkrag nie. Een-honderd-en-twee ( $52 \%$ ) van die studentverpleegkundiges was teleurgesteld omdat daar nie voldoende in hul opleidingsbehoeftes voorsien is nie. Faktore wat 'n rol gespeel het was onder andere: die saalsuster was altyd te besig; daar was nie tyd vir onderrig of opleiding nie; hulle word weggewys met 'n belofte dat die saalsuster later sal verduidelik en dan word dit nie opgevol g nie; die saalsusters beskik nie oor die nodige kennis nie en verwag dat hulle alles behoort te weet.

Verdere redes wat deur hierdie $102(52 \%)$ studentverpleegkundiges aangevoer word as faktore wat gelei het tot die nie-bevrediging van hul opleidingsbehoeftes, het betrekking op werksprosedures. Die gebrek aan voldoende tyd en aandag wat daartoe lei dat hulle verkcerde tegnicke en gewoontes aanleer; die feit dat metodes en wyses waarop prosedures uitgevocr word, van saalsuster tot saalsuster verskil en laastens die feit dat hul betreklik min tydens die betrokke maand geleer het en dus steeds onseker was omtrent die prosedures wat in die loop van die maand ter sprake was.

Bogenoemde 102 (52\%) studentverpleegkundiges het ook melding gemaak dat daar telkens nagelaat is om die nodige tyd aan hul opleiding af te staan. Hulle moes in hul vrye tyd lesings en demonstrasies bywoon omdat hulle nie tydens amptelike dienstyd vrygestel kon word nie. Selfs evaluerings moes in eie tyd geskied.

3. Die saalsuster se betrokkenheid by
kwaliteit-pasiëntsorg

Hoë verpleegsorgstandaarde

Die saalsuster is gesteld op die handhawing van hoe verpleegsorgstandaarde. Honderd-enveertig $(71 \%)$ studentverpleegkundiges het aangedui dat die saalsusters deur streng kontrole die uitvoering daarvan nastreef. Dit blyk egter volgens $56(29 \%)$ van die respondente dat deurlopende hoe kwaliteit verpleegsorg nie altyd gehandhaaf word nie, hoofsaaklik vanwee die volgende redes: taaktoewysing in plaas van die nastrewing van die totaliteitsbeginsels in verpleegsorg; die kwaliteit van die verpleegsorg word bepaal deur die bepaalde saalsuster aan diens; onsekerheid met betrekking tot die uitvoering van prosedures; hoofsaaklik eerstejaars is verantwoordelik vir die basiese versorging van pasiente en ondergeskiktes word nie op eenvormige wyse deur hul meerderes onderrig nie.

\section{Persoonlike versorging van pasiënte}

Dit blyk dat die saalsuster nie 'n genoegsame deel van haar tyd aan die persoonlike versorging van pasiënte afstaan nie. Volgens 113 (58\%) studentverpleegkundiges het hul saalsusters soms $(n=85 ; 43 \%)$ of nooit $(n=28 ; 15 \%)$ persoonlik by die verlening van pasiëntesorg betrokke geraak nie. Die saalsusters het egter aangedui dat 97 (81\%) van hulle dikwels persoonlik basiese verpleegsorg verleen.

Gesamentlike versorging van die pasiênt deur die saalsuster en die studentverpleegkundige vind volgens $110 \quad(56 \%)$ studentverpleegkundiges altyd of dikwels plaas. Hierteenoor het $94(78 \%)$ van die saalsusters aangetoon dat hulle dikwels saam met die studentverpleegkundiges werk in die voorsiening van basiese verpleegsorg. Volgens die saaisusters verleen $101(84 \%)$ van die respondente daaglikse verpleegsorg aan hul pasiënte.

\section{Die paraatheid van die saalsuster}

Korrelasie tussen teorie en praktyk

Vir optimale korrelasie tussen teorie en praktyk is dit noodsaaklik dat die saalsuster se teoretiese agtergrond met betrekking tot onder andere siektetoestande, medikasie, ondersoeke en bepaalde behandeling wat in haar saal van toepassing is, goed op die hoogte sal wees.

Die saalsusters moes antoon in watter mate hulle die toepaslike teoretiese inligting in hulle sale aan die studentverpleegkundiges kon verskaf. Die reaksie van die respondente (saalsusters) word in Tabel 1 weergegee.

\section{Kliniese paragtheid}

Die bevindinge dui daarop dat die saalsuster ook op kliniese vlak nie optimale kennis en vaardighede handhaaf nie. Slegs $56(47 \%)$ van die saalsusters het gemeen dat hulle klinies ten volle paraat was, terwyl 64 (53\%) aangedui het dat hulle nie ten volle paraat was met betrekking tot kliniese aangeleenthede in hulle sale nie.

\section{llantering van pasiëntekrisis}

Vier-en-vyftig (28\%) studentverpleegkundiges kon altyd en 79 (40\%) kon dikwels op die saalsuster staat maak om tydens 'n noodsituasie 
TABEL 1

BEANTWOORDING VAN VRAE GESTEL DEUR DIE STUDENTVERPLEEGKUNDIGES

\begin{tabular}{|l|c|c|c|c|c|c|}
\hline \multirow{2}{*}{$\begin{array}{c}\text { Beentwoording } \\
\text { van vrae }\end{array}$} & \multicolumn{2}{|c|}{ Sueter-in-bevel } & \multicolumn{2}{c|}{ Susters } & \multicolumn{2}{c|}{ Totaal } \\
\cline { 2 - 7 } & $\mathrm{N}=47$ & $\%$ & $\mathrm{~N}=37$ & $\%$ & $\mathrm{~N}=120$ & $\%$ \\
\hline Ja altyd & 23 & 19 & 27 & 23 & 50 & 42 \\
\hline Soms & 17 & 14 & 35 & 29 & 52 & 43 \\
\hline Nee & 7 & 6 & 11 & 9 & 18 & 15 \\
\hline
\end{tabular}

met 'n pasiënt, die verpleegsorg en die hantering van die pasiènt waar te neem. Drie-en-sestig (32\%) van die studentverpleegkundiges het gevoel dat hulle nie op die kundigheid en ervaring van die saalsuster in bogenoemde gevalle kon staat maak nie.

In teenstelling hiermee het die saalsusters aangedui dat $105(88 \%)$ van hulle altyd of dikwels pasiëntekrisisse hanteer. Redes wat deur die 15 saalsusters angevoer is vir hul afwesigheid tydens die hantering van pasiëntekrisisse is dat hulle so gou moontlik mediese hulp moes kry; dat hul ondergeskiktes die situasie heeltemal bevredigend kon hanteer en dat hul onseker was met betrekking tot die hantering van so 'n noodsituasie.

\section{LEEMTES IN DIE VERPLEEGPRAKTYK}

\section{Die saalsuster as rolmodel}

Die saalsuster as geregistreerde verpleegkundige blyk nie altyd bewus te wees van haar beinvloedingskrag as rolmodel nie.

Volgens 109 (56\%) studentverpleegkundiges het hulle hul saalsusters as verteenwoordigend beskou van die ideaal wat sy vir haarself voorgehou het. As motivering vir die stelling het die respondente dit as volg gestel: die saalsuster straal selfvertroue uil; sy is in beheer, is professioneel en simpatiek; sy is vriendelik, streng, regverdig en sonder nie mense uit nie. Sy weet genoeg en kan alles doen wat van haar verwag word. Sy is 'n goeie voorbeeld, nederig, hulpvaardig en betroubaar. Sy ondersteun die studentverpleegkundige indien laasgenoemde onseker is. Daarenteen het $87(44 \%)$ van die studentverpleegkundiges nie hul saalsusters as nastrewenswaardige rolmodelle beleef nie. Die volgende faktore is aangevoer as redes vir hul negatiewe belewing: wil nie soos sy 'n dienskamer-suster wees nie; haar optrede is dikwels onprofessioneel; beter interpersoonlike verhoudinge en groter belangstelling in haar pasiěnte en kollegas is 'n vereiste. Sy behandel nie haar personeel menswaardig nie; haar ondergeskiktes het 'n vrees vir haar; hulle word enersyds as kinders behandel terwyl sy self geen daadwerklike poging aanwend om hulle te leer of self by haar pasiènte betrokke te raak nie.
Haar temperament was wisselvallig en sy het 'n negatiewe houding tcenoor haar pasiënte en ondergeskiktes weerspiečl. Die saalsuster is nie vaardig en kundig nie en raak verbouereerd tydens krisisse.

\section{DIE SAALOMGEWING AS WERK- EN LEEROMGEWING}

\section{Die saalatmosfeer}

\section{Gespanne atmosfeer}

Dit blyk dat die grootste antal studentverpleegkundiges $(n=138 ; 70 \%)$ van mening was dat daar gewoonlik 'n aangename ontspanne atmosfeer in hul sale geheers het. Ongeag die werksdrukte het al die personeel as span saamgewerk; goeie organisasie, wedersydse ondersteuning en 'n eenheidsgevoel het daartoe bygedra dat die personeel die sale as 'n positiewe werkomgewing beleef het. Hierdie siening word deur die saalsusters bevestig deurdat 84 (70\%) van hulle ook aangedui het dat die saalomgewing gewoonlik ontspanne is ten tye van die werksdruk.

Dertig persent van beide die studentverpleegkundiges ( $n=55 ; 30 \%$ ) en die saalsusters $(n=36 ; 30 \%)$ het aangetoon dat die atmosfeer in hul sale dikwels gespanne was. Die studentverpleegkundiges het die volgende redes aangevoer: dit was altyd 'n dolle gejaag om die werk af te handel; personeel het nie van die saal gehou nie; spanning omdat hulle nie geweet het hoe om die prosedures uit te voer nie; die saalsuster was foutvinderig en haar bui was ' $n$ bepalende faktor vir die spanningsvlak in die saal.

Aspekte wat deur die saalsusters geïdentifiseer is as redes vir ' $n$ gespanne atmosfeer is onder andere: onvoldoende personeel; spanning veroorsaak deur ander spanlede; die werklading is onhanteerbaar; persoonlikheidsbotsings met ondergeskiktes; en die personeel is swak werkers.

Invloed op die leeringesteldheid van die studentverpleegkundige

Die oorgrote meerderheid van die saalsusters $(n=117 ; 98 \%)$ het bevestig dat die sualatmosfeer wel 'n belangrike invloed op die studentverpleegkundige se leeringesteldheid uitoefen. Die saalsusters het aangetoon dat studentverpleegkundiges deurentyd angemoedig en begelei behoort te word.

Leerbehoeftes van die studentverpleegkundige

Vyf-en-negentig (48\%) van die studentverpleegkundiges was tevrede met die wyse waarop die saalingesteldheid hulle as leerders ondersteun het. Meer as die helfte van die studentverpleegkundiges $(n=101 ; 52 \%)$ is egter van mening dat hul bepaalde saalomgewing hom nie tot die bevrediging van hul leerbehoeftes geleen het nie. Die faktore wat as belemmerend beskou is, is kortliks die volgende: studente moet self moeite doen om leergeleenthede te skep; daar is geen gestruklureercie onderrigprogram nie; na 'n eenmalige demonstrasie moes hulle weet hoe om 'n bepaalde prosedure uit te voer; hul vrye tyd moes vir opleiding afgestaan word; die werklading het nie genoegsame tyd toegelaat vir onderriggeleenthede nie; dic saalsuster het aanvaar dat haar ondergeskiktes weet wat in die saal aangaan; te veel word van die studentverpleegkundige verwag sonder die nodige leiding. Verder is die studentverpleegkundige van mening dat die saalsuster in hierdie sale min belangstelling getoon het sel fs al was die sale stil en was daar genoeg tyd. Daarbenewens was die saalsuster nie bereid om betrokke te raak nie.

Die oorgrote meerderheid van die saalsusters $(n=108 ; 90 \%)$ het aangetoon dat die saalsuster die leeromgewing van die studentverpleegkundige in die saalsituasie kan beïnvloed. Minder as die helfte van die studentverpleeg. kundiges $(n=92 ; 47 \%)$ het gevoel dat daar begrip vir hul omstandighede as student was.

Terugvoering aan studentverpleegkundiges Die meeste studentverpleegkundiges $163(83 \%)$ het dit waardeer dat hulle direk deur die saalsuster genader is wanneer laasgenoemde nie tevrede was met hul houding of werkverrigting nie. Die corblywende 33 (17\%) moes op 'n indirekte wyse hoor dat die saalsuster ontevrede was.

Dit blyk dat goeie kommunikasievaardighede deur meeste van die saalsusters $(n=107 ; 89 \%)$ gehandhaaf word wanneer dit kom by die konfrontering van ondergeskiktes. Hierdie saalsusters het aangetoon dat hulle die studentverpleegkundige in privaatheid aanspreek.

Dit kom voor dat positiewe terugvoering vir goed afgehandelde take en opdragte nie maklik deur studentverpleegkundiges verdien word nie, aangesien slegs $83(42 \%)$ van die respondente dikwels positiewe terugvoering ontvang het. Daarenteen dui 117 (98\%) van die saalsusters aan dat hulle positiewe terugvoering aan hulle ondergeskiktes gee wanneer hulle dit verdien. 
Jie saalsuster se belewing van haar werk re midde van al haar verpligtinge het die neerderhcid saalsusters $(\mathrm{n}=111 ; 91 \%)$ aangedui lat hulle hul werk geniet, sommige het selfs langedui dat hulle dit baie geniet.

\section{IANBEVELINGS}

tanbevelings wat moontlik kan bydra tot meer loeltreffende onderrig in die kliniese praktyk is Is volg:

\section{Die opleidingsfunksie van die saalsuster}

- Bepaalde bestuursvaardighede is essensieel vir doeltreffende saalbestuur; aandag bchoort geskenk te word aan aspekte soos die toepaslikheid van verskillende leierskapstyle, werkverdeling en probleemoplossing.

- Die doeltreffendheid van bestaande oriënteringsprogramme kan verhoog word deur dit met gestruktureerde, geskrewe programme te ondersteun wat later as verwysingsbron kan dien. Die oriěnteringsprogram behoort na afloop van 'n bepaalde tyd deur elke personeellid evalueer te word.

- Die beplanning, organisering en implementering van kliniese onderrig in die saalsituasie moet op 'n spanpoging berus.

- Opleiding in sale behoort op 'n gestruktureerde en doelgerigte wyse plaas te vind.

- Terwyl personeeltekorte steeds aan die orde van die dag is en dienslewering sowel as opleiding moet voortgaan, word voorgestel dat 'n ervare saalsuster in elke saal, as bykomende plig, die verantwoordelikheid vir opleiding, sal aanvaar.

- Geleentheid behoort op gereelde grondslag geskep te word vir alle betrokke saalpersoneel, om relevante sake wat 'n invloed op die funksionering van die saal mag uitoefen, te bespreek.

- Voorsiening behoort gemaak te word vir nouer en gereelde skakeling lussen die saalsuster, kliniese dosent asook die teoretiese dosent.

\section{Leemtes in die verpleegpraktyk}

- Groter klem en inoefening met betrekking tot haar opleidingsfunksie behoort op die senior studentverpleegkundige geplaas te word sodat sy beter voorbereid en met die korrekte ingesteldheid haar rol as saalsuster na afloop van haar opleiding kan aanvaar.

- Toepaslike indiensopleiding vir die salsuster met in agneming van die volgende aspekte: beter insae in alle opleidingsaspekte van die basiese studentverpleegkundige; die belangrikheid van eenvormigheid, veral met betrekking tot die uitvoering van prosedures; die bydrae wat sy kan lewer ten opsigte van die leeringesteldheid van haar ondergeskiktes en krisishantering.

- Paraatheid van die saalsuster met betrekking tot die toepaslike teorie en kliniese vaardighede moet voorrang geniet. Dit is egter essensieel dat die opknapping van kennis in 'n geïsoleerde, veilige omgewing sal plaasvind. Die inoefening van noodsituasies kan nie beplan word nie derhalwe kan 'n saalsuster wat onseker voel vir 'n paar maande in noodgevalle ondervinding opdoen, totdat sy meer tuis is met die onverwagte.

- Die saalsuster se mag en beïnvloedingskrag as rolmodel moet meer aandag geniet. Deur middel van 'n kursus in interpersoonlike vaardighede kan die saalsuster leer om met groter noukeurigheid $\mathrm{klem}$ op goeie interpersoonlike verhoudinge te plaas. Hierdie vaardighede behoort van tyd tot tyd herbevestig te word.

- Die minimum vereistes wat ten opsigte van die studentverpleegkundige se kliniese praktika verwag word, behoort op sinvolle wyse hersien te word om die stres op die student te verminder.

3. Die saalomgewing as werks- en leeromgewing

- Meer aandag behoort aan die studentverpleegkundiges as student gegee te word. Dit is veral belangrik dat sy kliniese praklika as deel van haar opleiding sal beleef en nie bloot as haar bydrae tot dienslewering nie.

- Alle kliniese onderrig en evaluering behoort binne die perke van haar $\mathbf{4 0}$ uur per week amptelike dienstydperk te geskied.

- Die belangrike rol van die saalsuster in die skepping van 'n positiewe leeromgewing vir die studentverpleegkundige, moet steeds uitgebrei word. Die saalsuster behoort die ondersteuning en hulp van haar meerderes in hierdie verband, sonder huiwering te ontvang.

- Die beginsel van spanwerk as wyse van pasientesorg, behoort uitgebrei te word om sover moontlik toegepas te word.

- Kliniese dosente behoort aan 'n bepaalde saal loegewys te word, vanwaar hul optree en funksioneer. Voorkeur behoort gegee te word aan die begeleiding van die studentverpleegkundige waar sy besig is met haar taak in die saal.

\section{SAMEVATTING}

Die salsuster is die sentrale figuur in elke saalsituasie, aangesien sy die bepalende faktor vir onder meer die saalorganisasie, kwaliteit van pasiëntsorg, saalatmosfeer en die leeringesteldheid van haar ondergeskiktes is. Die saalsuster dien ook as die belangrikste rolmodel vir die studentverpleegkundige waarvolgens haar professionele vorming geskoei word.

Dit blyk egter dat bepaalde leemtes bestaan met betrekking tot die saalsuster se betrokkenheid by direkte basiese verpleegsorg van pasiente, die opleiding van studentverpleegkundiges en die belangrike beïnloedingskrag waaroor sy as rolmodel geskik.

\section{BIBLIOGRAFIE}

ANDREWS, G.A. Complete nursing care - 2 The feelings of the ward sister. Nursing Times, 76(34), August 1980: 1484-1486.

ASHURST, A. Teaching for tomorrow Nursing Mirror, 158(10), March 1984:25.

BEEKMAN, A.W. Hanteer die studentverpleegkundige as wardige mens. Curationis, 5(2), Junie 1982:9-10.

DARLING, L.A.W. Becoming a mentoring manager. The Journal of Nursing Administration. June 1985:43-44.

DUBERLEY, J. The clinical nurse specialist. Nursing Times. 72(46), November 1976 : 1794-1795.

FRETWELL, J.E. An inquiry into the ward learning environment. Nursing Times. 76(26), June 1980: 69-75.

GARITY, J. Developing head nurses: One hospital's solution. Nurse Educator, Autumn 1983: 38-42.

GRIFFITH, J.W. Supervisor's rating of baccalaureate nurse competencies. Supervisor Nurse. 11(10) October 1980: 20-24.

KOTZE, W.J. Begeleiding in die verpleegkunde. Pretoria: Die Suid-Afrikaanse Verpleegstersvereniging.

KUSHNIR, T. Stress and social facilitation: The effects of the presence of an instructor on student nurse's behaviour. Journal of Advanced Nursing. 1, 1986: 13-19.

LAROCCO, S.A. An introduction to role theory for nurses. Supenvisor Nurse. 19(12) December 1978: 41-45.

LOUDON, H. Trends in nursing in South Africa and their implications for nursing education. Curationis. 7(2), June 1984: 8-11. 
MARKHAM, G. "You're always so busy, sister". Nursing Mirror 151(12), September 1980: 38-40.

MELLISH, J.M. 1982. Teaching the practice of nursing. Durban: Butterworths.

MILLER, A. Right for the job? Nursing Times. 81(25), June 1985: 44-46.

PERREIRA, J. The role of the ward sister in the guidance and assistance of the student nurse along the rood to professional adulthood. Die Studentverpleegkundige Quo Vadis.
Port Elizabeth: Universiteit van Port Elizabeth. 1981: 53-54.

RHEINER, N.W. Role theory framework for change. Nursing Management. 13(3) March 1982: 20-22.

SEARLE, C. The ward sister - some aspects of her role and function. Curationis. 4(2), Seprember 1981: 21-24.

SMIT, E.C. Volwassewording van die student in die pedagogiese sin. Die Studentverpleegkundige Quo Vadis. Port
Elizabeth: Universiteit van Port Elizabeth 1981: 23-28.

SPERO, J. Nursing: A professional practice discipline in academia. Nursing \& Health Care, 1(1), August 1980: 22-25.

$$
\begin{gathered}
\text { Mej. Marthic C Bezuidenhout } \\
\text { MCur } \\
\text { Departement van Verpleegkundige } \\
\text { Randse Afrikaanse Universiteit } \\
\text { Professor A A Basson } \\
\text { Departement van Verplecgkundige } \\
\text { Randse Afrikaanse Universiteit }
\end{gathered}
$$

